\title{
Prevalence and associated risk factors for Hepatitis $B$ and $C$ viruses among refugees in Gambella, Ethiopia
}

\author{
Abiyu Ayele ${ }^{1}$, Dessie Abera2* ${ }^{2}$, Melese Hailu², Muluken Birhanu ${ }^{3}$ and Kassu Desta ${ }^{2}$
}

\begin{abstract}
Background: Currently, there is an increased flow of refugees into Ethiopia from neighboring countries. However, there are no post-arrival screening mechanisms for hepatitis B and C viruses which could be an additional burden for the local population. Hence, this study aimed to determine the prevalence and associated risk factors for hepatitis B and C viruses among refugees in Gambella, Ethiopia. It also aimed to determine the knowledge, attitude, and practice concerning hepatitis $B$ and $C$ viruses among participants.

Methods: A cross-sectional study was conducted among 453 refugees in Gambella, Ethiopia from January until May 2018. A questionnaire was used to collect data on refugees' socio-demographic, risk factors, and KAP of hepatitis B and C infections. Five milliliters of blood sample were collected from each participant and the serum was used for HBsAg and anti-HCV antibody screening rapid tests. Positive samples were further tested by ELISA method. Data were performed using SPSS version 20, and a $p$-value less than 0.05 was considered statistically significant.
\end{abstract}

Results: The overall prevalence of HBsAg and anti-HCV among refugees was 7.3\% (33/453) and 2.0\% (9/453) respectively. Of these, $6.8 \%$ (25/370) and 1.4\% (5/370) of females were positive for HBsAg and anti-HCV, whereas 9.6\% (8/83) and 4.8\% (4/83) of males were positive for HBsAg and anti-HCV. The age group of 18-29 and 30-41 years old were related to HCV infection $(P=0.003$ and $P=0.020)$. However, proposed risk factors were not related to HBV and HCV infections. Knowledge assessment showed that 86.5\% (392/453) did not know how HBV and HCV infections are transmitted, and 86.8\% (393/453) had no information about the availability of HBV vaccine.

Conclusion: This study showed intermediate prevalence of hepatitis B and hepatitis C virus in a large refugee camp in Ethiopia. The prevalence of hepatitis $C$ virus was found to increase with age, but no other risk factor for either virus identified as significant. Refugees' understanding of hepatitis B and C was very limited. This indicates the need for screening policy to be implemented and integrated with other health services and awareness creation about the infection in all refugee camps of Gambella.

Keywords: HBV, HCV, Refugees, Gambella, Ethiopia

\footnotetext{
* Correspondence: dessabera@gmail.com

${ }^{2}$ Department of Medical Laboratory Sciences, College of Health Sciences,

Addis Ababa University, Addis Ababa, Ethiopia

Full list of author information is available at the end of the article
}

(c) The Author(s). 2020 Open Access This article is licensed under a Creative Commons Attribution 4.0 International License, which permits use, sharing, adaptation, distribution and reproduction in any medium or format, as long as you give appropriate credit to the original author(s) and the source, provide a link to the Creative Commons licence, and indicate if changes were made. The images or other third party material in this article are included in the article's Creative Commons licence, unless indicated otherwise in a credit line to the material. If material is not included in the article's Creative Commons licence and your intended use is not permitted by statutory regulation or exceeds the permitted use, you will need to obtain permission directly from the copyright holder. To view a copy of this licence, visit http://creativecommons.org/licenses/by/4.0/ The Creative Commons Public Domain Dedication waiver (http://creativecommons.org/publicdomain/zero/1.0/) applies to the data made available in this article, unless otherwise stated in a credit line to the data. 


\section{Background}

Globally, hepatitis B virus (HBV) and hepatitis C virus $(\mathrm{HCV})$ are major public health problems, particularly in developing countries [1]. The majority of the people, $40-80 \%$ living with chronic hepatitis B or C are unaware of their serostatus and they remain infectious to others [2]. Chronic liver disease, due to HBV and HCV continues to be the most challenging problem in economically poor countries [3].

Refugee populations are at risk of contracting HBV and HCV infections because of a lack of access to health care services and the inability to obtain information about the transmission and prevention ways of these infections from the media $[4,5]$. In addition, social and cultural norms, sexual violence, ritual scarification, as well as separation from a spouse may increase the risk of getting hepatitis infections due to HBV and HCV. Furthermore, isolation and stress may also lead the refugees to engage in risky behavior, which escalates the risk of these infections [6]. Although the extent of transmission potential varies, $\mathrm{HBV}$ and $\mathrm{HCV}$ share a common mode of transmission, which are unsafe sexual intercourse, percutaneous or mucosal exposure to the blood or body fluids of an infected person, exposure to unscreened blood transfusions or unsafe injections in health care settings and by intravenous drug use [7]. The risk of $\mathrm{HBV}$ and HCV transmission is strongly associated with the origin from countries in which these infections are endemic, lack of information on hepatitis prevention, history of sharp injury, blood donation, family history of liver disease, tooth extraction, and tattooing [7].

About 350 to 400 million people are infected with HBV worldwide and it is the cause of death for 1 million people each year. Furthermore, 130 to 170 million people are infected with HCV worldwide, which causes about 350,000 deaths per year [8]. The World Health Organization (WHO) classifies countries, according to the hepatitis B surface antigen (HBsAg) prevalence, into low $(<2 \%)$, intermediate (2-8\%), and high (> 8\%) prevalence [9].

Ethiopia is classified under the geographical regions with intermediate viral hepatitis infections [10]. HBsAg prevalence in sub-Sahara Africa ranges from 8 to $15 \%,[11,12]$, whereas the prevalence of HCV in sub-Saharan Africa ranges from 0.1 to $13.8 \%$ [13]. A meta-analysis report in Ethiopia indicated that the estimated prevalence of $\mathrm{HBsAg}$ and anti-HCV antibody was 7.4 and $3.1 \%$ respectively [14].

The flow of refugees into Ethiopia is increased from time to time and ranked the second most populated refugee asylum countries in Africa. The majority of them are originated from Somali, Eritrea, Sudan, and South Sudan, which have a high prevalence of hepatitis B and C $[3,15,16]$. For instance, a meta-analysis report from Sudan indicated that the prevalence of hepatitis B surface antigen (HBsAg) and $\mathrm{HCV}$ - antibodies were 12.07 and $2.74 \%$ respectively [17], and a study from South Sudan estimated the prevalence of HBV to be $11 \%$ [18]. Refugees cross the border of the country without any health screening and live in different refugee camps in close proximity to the local inhabitants. As a result, different diseases can be transmitted from refugees to the local population unless extended health education and preventive mechanisms are planned by the country. In addition, Ethiopian public health policies do not focus on screening refugees for hepatitis $\mathrm{B}$ and $\mathrm{C}$ viral infection (13). Therefore, early detection is crucial, to prevent transmission, progression of liver disease and to decrease morbidity and mortality. So, this study aimed to determine the prevalence and associated risk factors for hepatitis B and C viruses among refugees in Gambella, Ethiopia. It also aimed to determine the knowledge, attitude, and practice concerning hepatitis $\mathrm{B}$ and $\mathrm{C}$ viruses among participants.

\section{Methods \\ Study design, period and setting}

A cross-sectional study was conducted from January 2017 until May 2018 at Pugnido-I refugee camp in Gambella, Ethiopia. The study area is located in the southwest of Ethiopia and borders with South-Sudan. It is $711 \mathrm{~km}$ from Addis Ababa, the capital city of Ethiopia. In Gambella, there are six refugee camps, with a total number of 285,846 refugees, namely Pugnido-II $(16,820)$, Nguenyyiel $(28,243)$, Kule $(51,272)$, Jewi $(56,989)$, Pugnido-I $(62,925)$ and Tierkidi $(69,597)$. Inhabitants of Pugnido-I refugee camp were primarily originated from South Sudan. We have observed that adult male participants were very few in the camp because they have stayed in their country to fight.

\section{Study participants, sampling technique and sample size determination}

A list of all the refugee camps in the study area was obtained from the administration for refugee and returnee Affair (ARRA), Addis Ababa, Ethiopia. Accordingly, there are six refugee camps, and from these refugee camps, Pugnido-I refugee camp was selected as a study site using a purposive sampling technique because of the availability of a well-organized laboratory and a huge number of refugees in the camp. After that, all refugees visiting Pugnido-I camp health center during the study period and who volunteered to participate in the study were enrolled conveniently.

The sample size was determined by using the single population proportion formula, $n=(\mathrm{Z} \alpha / 2)^{2} \mathrm{P}(1-\mathrm{P}) / \mathrm{d}^{2}$, with a marginal error of 5 , and $95 \%$ confidence interval [19]. Data on the prevalence of HBV among refugees in the study setting was not available, however, it is expected to be in the range of $8-15 \%$ [20]. Therefore, we 
used $15 \%$ to increase the sample size, accordingly, the sample size was determined to be 196 . To minimize errors arising from the likelihood of non-response, $10 \%$ $(10 \%)$ of the sample size was added giving a final minimum sample size of 216. Nevertheless, we have collected 453 samples.

\section{Data collection}

Written consent was obtained from study participants and an interviewer-administered questionnaire was used to interview participants about their socio-demographic characteristics (age, sex, marital status, and educational status), and we also assessed their exposure to potential risk factors of HBV and HCV infections, such as the habit of sharing sharp materials, history of tattooing and other risks. In addition, knowledge, attitude, and practice towards $\mathrm{HBV}$ and $\mathrm{HCV}$ infections were assessed using yes/or no questions focusing on the cause, transmission, prevention and treatment of viral hepatitis due to HBV and $\mathrm{HCV}$. The questionnaire was prepared in the English language and supervisors helped to translate for those who did not communicate in English. The cut- off value for adequate knowledge, attitude, and practice was defined as $70 \%$ or more questions were correctly answered. The questionnaire was developed and adapted after detail review of relevant literatures [21-24]. The English version of the questionnaire is supplied as a supplementary document (See Additional file 1).

\section{Laboratory analysis}

After obtaining the participants' written consent, $5 \mathrm{ml}$ of the blood sample was collected from each refugee. Each blood samples were allowed to clot and serum was separated by centrifuging at $3000 \mathrm{rpm}$ for $5 \mathrm{~min}$ and all serum samples were tested for HBsAg and anti-HCV rapid test strips (Eco test) according to the manufacturer's instruction. All serum samples which were positive for HBV and HCV further tested with Enzyme-Linked Immunosorbent Assay (ELISA) at Ethiopian Public Health Institute (EPHI). During testing, standard operating procedures (SOPs) were followed for each laboratory analysis, and known positive and negative serums for HBV and HCV tests were used as a control to avoid false positive and negative results.

\section{Statistical analysis}

Data were coded, entered, and analyzed by SPSS software version 20. Descriptive statistics were performed to describe the frequency of categorical variables, such as the socio-demographic characteristics, risk factors and knowledge, attitude, and practice, as well as to estimate the prevalence or proportion of $\mathrm{HBV}$ and $\mathrm{HCV}$ infections. The associations of potential risk factors with $\mathrm{HBV}$ and HCV infections were assessed using binary logistic regression. Moreover, all variables with a $P$-value
$<0.25$ in the bivariate analysis were included in the multivariate logistic regression model, to look if the association existed after controlling against all the rest of the variables, and a cut off value less than 0.25 is supported by the literature $[25,26]$. Odds ratio (OR) at $95 \%$ confidence interval $(\mathrm{CI})$ was calculated and a $p$-value < 0.05 was considered as statistically significant.

\section{Ethical approval}

The study was approved by the Departmental Research and Ethics Review Committee (DRERC) of Addis Ababa University, Department of Medical Laboratory Sciences, Ethiopia. A letter of permission was obtained from the office of the Administration of Refugees and Returnees Affair (ARRA) and UNHCR, Ethiopia. Written informed consent was obtained from the study participants after they have been clearly briefed about the objective of the study. They were informed about their right to refuse to participate in the study and to withdraw at any time during the study without jeopardizing their right to access other health services. Test results were kept confidential by using unique codes given to each study participant. All positive results were communicated to the attending physician.

\section{Results}

\section{Socio-demographic characteristics}

During the study, 473 volunteer refugees gave their consent to participate. Nine participants were excluded because of the incompleteness of the questionnaire, and eleven hemolyzed blood specimens were rejected, with the total exclusion of $4.2 \%$ (20/473). Finally, 453 participants who gave both blood specimens and questionnaire responses were included in the analysis. The majority of the participants, $370(81.7 \%)$ were females and the age range of the participants was 18-61 years old with a mean age of $29.6 \pm 9.3 \mathrm{SD}$ years. Concerning marital status, $379(83.7 \%)$ of them were married. Data on educational status showed, 166 (36.6\%) were elementary level and roughly the same number, 165 (36.4\%) were illiterate (Table 1).

\section{The prevalence of $\mathrm{HBsAg}$ and anti-HCV antibody}

Out of 453 participants, 7.3 and $2.2 \%$ were positive for HBsAg and anti-HCV rapid tests respectively. Nearly the same prevalence was found with ELISA, which was used as a confirmatory test, $7.3 \%$ (33/453) prevalence of HBsAg, and 2.0\% (9/453) prevalence of anti-HCV. The detection rate of HBsAg and anti-HCV in female participants was $6.8 \%(25 / 370)$ and $1.4 \%(5 / 370)$, whereas it was $9.6 \%(8 / 83)$ and $4.8 \%(4 / 83)$ among males respectively. A slightly higher proportion of HBsAg (12.1\%) was detected among increased aged groups (30-41 years old). The positivity rate for both HBsAg,7.7\% (29/379), and anti-HCV, 2.4\% (9/379) among married participants 
Table 1 Socio-demographic characteristics of the study participants in Gambella, Ethiopia, 2018 ( $n=453)$

\begin{tabular}{|c|c|c|c|}
\hline \multicolumn{2}{|l|}{ Variables } & \multirow{2}{*}{$\frac{\text { Frequency }(\mathrm{n})}{370}$} & \multirow{2}{*}{$\begin{array}{l}\text { Percentage (\%) } \\
81.7\end{array}$} \\
\hline Sex & Female & & \\
\hline & Male & 83 & 18.3 \\
\hline \multirow[t]{3}{*}{ Age category } & $18-29$ & 231 & 51.0 \\
\hline & $30-41$ & 107 & 23.6 \\
\hline & $>41$ & 115 & 25.4 \\
\hline \multirow[t]{4}{*}{ Marital status } & Single & 25 & 5.5 \\
\hline & Married & 379 & 83.7 \\
\hline & Divorced & 22 & 4.9 \\
\hline & Widowed & 27 & 6.0 \\
\hline \multirow[t]{4}{*}{ Education } & Illiterate & 165 & 36.4 \\
\hline & Elementary & 166 & 36.6 \\
\hline & High school & 104 & 23.0 \\
\hline & Higher education & 18 & 4.0 \\
\hline
\end{tabular}

was higher than among participants with other marital statuses. Participants who were educated at elementary level showed a high prevalence of HBsAg $12.0 \%$ (20/166) and anti-HCV 3.0\% (5/166) (Table 2).

\section{Risk factors associated with prevalence of $\mathrm{HBsAg}$}

The proportion of $\mathrm{HBsAg}$ positivity was higher among male participants, 9.6\% (8/83) than among female participants, 6.8\% (25/370), however, the difference was not statistically significant $(P=0.364)$. Regarding the marital status, $7.7 \%(29 / 379)$ of the married participants were positive for HBsAg and 7.4\% (2/27) of the divorced participants was positive for HBsAg. Data from educational status showed that $12.0 \%(20 / 166)$ positive for $\mathrm{HBsAg}$ were educated at the elementary level. Participants who had an exchange of sharp materials with others turned out to have a slightly higher positivity of HBsAg, 6.3\% (12/106) compared to participants who had no exchange of sharp materials with others. About 6.1\% (21/347) of the refugees who had multiple sex partners were positive for HBsAg. Exchange of sharp materials, marital status, educational status and other proposed risk factors were not associated with HBV infection (Table 3).

Risk factors associated with anti-HCV antibody prevalence The proportion of anti-HCV (1.4\%) among female participants was lower than male participants (4.8), but the difference was not significant (COR $=0.27$, CI 95\% 0.07 $1.03, P=0.055)$. Statistically, significant association could be seen in the age group of $18-29$ and 30-41-years old participants with $\mathrm{HCV}$ infection $(\mathrm{COR}=2.52$, CI $95 \%=$ $1.81-6.36, P=0.002$ and $\mathrm{COR}=3.28, \mathrm{CI} 95 \%=2.02-9.54$, $P=0.017)$ compared to other age groups, respectively. Only $1.6 \%(1 / 64)$ anti-HCV positive participants had a history of exchange of sharp materials with others; however, no significant association with HCV infection was found $(P=0.794)$. In addition, multivariate logistic regression was performed to account for possible confounding variables and all variables with a $P$-value $<0.25$ in the bivariate analysis were included in the multivariate logistic regression analysis. Accordingly, adjusted odds ratio was calculated between different age groups and sex and HCV infection. The association remains significant among the age category of $18-29$ years $(\mathrm{AOR}=$ 2.47 , CI $95 \%=1.83-7.40, P=0.003)$ and age category of $30-41$ years old $($ AOR $=3.20$, CI $95 \%=2.78-8.11, P=$ 0.020 ), whereas sex was not significant with HCV infection $(P=0.083)$ as depicted in (Table 4$)$.

Table 2 Prevalence of HBV and HCV with ELISA among study participants in Gambella, Ethiopia, $2018(n=453)$

\begin{tabular}{|c|c|c|c|c|c|c|}
\hline \multirow[t]{2}{*}{ Variables } & & \multicolumn{2}{|l|}{$\mathrm{HBsAg}$} & \multicolumn{2}{|l|}{ Anti-HCV } & \multirow[t]{2}{*}{ Total } \\
\hline & & Positive (\%) & Negative (\%) & Positive (\%) & Negative (\%) & \\
\hline \multirow[t]{2}{*}{ Sex } & Female & $25(6.8)$ & $345(93.2)$ & $5(1.4)$ & $365(98.6)$ & 370 \\
\hline & Male & $8(9.6)$ & 75 (90.4) & $4(4.8)$ & 79 (95.2) & 83 \\
\hline \multirow[t]{3}{*}{ Age category } & $18-29$ & $15(6.5)$ & $216(93.5)$ & $5(2.2)$ & $226(97.8)$ & 231 \\
\hline & $30-41$ & $13(12.1)$ & $94(87.9)$ & $3(2.8)$ & $104(97.2)$ & 107 \\
\hline & $>41$ & $5(4.3)$ & $110(95.7)$ & $1(0.01)$ & 114 (99.99) & 115 \\
\hline \multirow[t]{4}{*}{ Marital status } & Single & $1(4.0)$ & $24(96.0)$ & $0(0)$ & $25(100)$ & 25 \\
\hline & Married & $29(7.7)$ & $350(92.3)$ & $9(2.4)$ & 370 (97.6) & 379 \\
\hline & Divorced & $1(4.5)$ & $21(95.5)$ & $0(0)$ & $22(100)$ & 22 \\
\hline & Widowed & $2(7.4)$ & 25 (92.6) & $0(0)$ & $27(100)$ & 27 \\
\hline \multirow[t]{4}{*}{ Educational status } & Illiterate & $7(4.2)$ & $158(95.8)$ & $4(2.4)$ & 161 (97.6) & 165 \\
\hline & Elementary & $20(12.0)$ & $146(88.0)$ & $5(3.0)$ & $161(97.0)$ & 166 \\
\hline & High school & $5(4.8)$ & $99(95.2)$ & $0(0)$ & $104(100)$ & 104 \\
\hline & University & $1(5.6)$ & 17 (94.4) & $0(0)$ & $18(100)$ & 18 \\
\hline
\end{tabular}


Table 3 Risk factors associated with prevalence of HBsAg using ELISA test among study participants in Gambella, Ethiopia, 2018 $(n=453)$

\begin{tabular}{|c|c|c|c|c|c|c|}
\hline Variables & & Total (\%) & $\begin{array}{l}\text { HBsAg } \\
\text { Positive (\%) }\end{array}$ & COR & $\mathrm{Cl}(95 \%)$ & $\boldsymbol{P}$-Value \\
\hline \multirow[t]{2}{*}{ Sex } & Male & 83 (18.3) & $8(9.6 \%)$ & 1.00 & & \\
\hline & Female & $370(81.7)$ & $25(6.8 \%)$ & 0.67 & $0.29-1.56$ & 0.364 \\
\hline \multirow[t]{3}{*}{ Age category } & $>41$ & $115(25.4)$ & $5(4.3)$ & 1.00 & & \\
\hline & $30-41$ & 107 (23.6) & $13(12.1)$ & 3.04 & $0.31-2.75$ & 0.894 \\
\hline & $18-29$ & $231(51.0)$ & $15(6.5)$ & 1.54 & $0.18-1.56$ & 0.258 \\
\hline \multirow[t]{4}{*}{ Marital status } & Single & $25(5.5)$ & $1(4.0)$ & 1.00 & & \\
\hline & Married & $379(83.7)$ & $29(7.7)$ & 1.98 & $0.26-15.23$ & 0.508 \\
\hline & Divorced & $22(4.9)$ & $1(4.5)$ & 1.14 & $0.06-19.42$ & 0.926 \\
\hline & Widowed & $27(6.0)$ & $2(7.4)$ & 1.92 & $0.16-22.58$ & 0.604 \\
\hline \multirow[t]{4}{*}{ Education status } & University & $18(4.0)$ & $1(5.6)$ & 1.00 & & \\
\hline & High school & $104(23.0)$ & $5(4.8)$ & 0.85 & $0.09-7.81$ & 0.892 \\
\hline & Elementary & $166(36.6)$ & $20(12.0)$ & 2.32 & $0.29-18.45$ & 0.424 \\
\hline & Illiterate & $165(36.4)$ & $7(4.2)$ & 0.75 & $0.08-6.49$ & 0.796 \\
\hline \multirow[t]{2}{*}{ Multiple sex partners } & No & $106(23.4)$ & $12(11.3)$ & 1.00 & & \\
\hline & Yes & 347 (76.6) & $21(6.1)$ & 0.50 & $0.23-1.06$ & 0.072 \\
\hline \multirow[t]{2}{*}{ Exchange of sharp materials } & No & $389(85.9)$ & $29(7.5)$ & 1.00 & & \\
\hline & Yes & $64(14.1)$ & $4(6.3)$ & 0.82 & $0.28-2.43$ & 0.731 \\
\hline \multirow[t]{2}{*}{ Tattooing history } & No & $435(96.0)$ & $32(3.4)$ & 1.00 & & \\
\hline & Yes & $18(4.0)$ & $1(5.6)$ & 0.74 & $0.09-5.74$ & 0.774 \\
\hline \multirow[t]{2}{*}{ Tooth extraction history } & No & $402(88.7)$ & $30(7.5)$ & 1.00 & & \\
\hline & Yes & $51(11.3)$ & $3(5.9)$ & 0.77 & $0.22-2.63$ & 0.683 \\
\hline \multirow[t]{2}{*}{ Vaccinated } & No & $444(98.0)$ & $32(7.2)$ & 1.00 & & \\
\hline & Yes & $9(2.0)$ & $1(1.1)$ & 1.60 & $0.19-2.27$ & 0.658 \\
\hline
\end{tabular}

COR Crude odds ratio, $\mathrm{Cl}$ Confidence interval

Knowledge, attitude and practices (KAP) assessment on HBV and HCV infection Knowledge of study participants

The majority of participants 79.2\% (359/453) had no knowledge about $\mathrm{HBV}$ and $\mathrm{HCV}$ infections and $86.5 \%$
(392/453) and $91.4 \%(414 / 453)$ did not know about the transmission of $\mathrm{HBV}$ and $\mathrm{HCV}$, respectively. About $89.0 \%(403 / 453)$ of the participants did not know the relationship between liver cancer and hepatitis B and C. Concerning vaccination, 86.8\% (393/453) did not have

Table 4 Risk factors associated with prevalence of anti-HCV antibody using ELISA test among study participants in Gambella, Ethiopia, $2018(n=453)$

\begin{tabular}{|c|c|c|c|c|c|c|c|c|c|}
\hline Variables & & Total (\%) & $\begin{array}{l}\text { Anti-HCV } \\
\text { Positive (\%) }\end{array}$ & COR & $\mathrm{Cl}(95 \%)$ & $\boldsymbol{P}$-Value & AOR & $\mathrm{Cl}(95 \%)$ & $\boldsymbol{P}$-Value \\
\hline \multirow[t]{2}{*}{ Sex } & Male & 83 (18.3) & $4(4.8)$ & 1.00 & & & 1.00 & & \\
\hline & Female & $370(81.7)$ & $5(1.4)$ & 0.27 & $0.07-1.03$ & 0.055 & 0.29 & $0.07-1.17$ & 0.083 \\
\hline \multirow[t]{3}{*}{ Age category } & $>41$ & $115(25.4)$ & $1(0.01)$ & 1.00 & & & & & \\
\hline & $30-41$ & 107 23.6) & $3(2.8)$ & 3.28 & $2.02-9.54$ & 0.017 & 3.20 & $2.78-8.11$ & 0.020 \\
\hline & $18-29$ & $231(51.0)$ & $5(2.2)$ & 2.52 & $1.81-6.36$ & 0.002 & 2.47 & $1.83-7.40$ & 0.003 \\
\hline \multirow[t]{2}{*}{ Multi sex partners } & No & $106(23.4)$ & $2(1.9)$ & 1.00 & & & & & \\
\hline & Yes & $347(76.6)$ & $7(2.0)$ & 1.07 & $0.21-5.23$ & 0.933 & & & \\
\hline \multirow{2}{*}{$\begin{array}{l}\text { Exchange sharp } \\
\text { Material }\end{array}$} & No & $389(85.9)$ & $8(2.1)$ & 1.00 & & & & & \\
\hline & Yes & $64(14.1)$ & $1(1.6)$ & 0.75 & $0.09-6.14$ & 0.794 & & & \\
\hline
\end{tabular}


any information about the availability of a vaccine against hepatitis B and 72.0\% (326/453) also did not have information on the treatment of HBV and HCV infection at all (Table 5).

\section{Attitude of study participants}

In this study, $8.2 \%(37 / 453)$ of the refugees believed that HBV and HCV infection could be transmitted by food and $11.5 \%(52 / 453)$ of the participants had the opinion that HBV and HCV are curable diseases. About $75.7 \%$ $(343 / 453)$ of the participants thought that HBV and $\mathrm{HCV}$ are not serious public health problems and $72.8 \%$ (330/453) of the participants believed that the vaccine of HBV is not safe (Table 5).

\section{Practice of study participants}

Regarding the vaccination, 98.5\% (446/453) were not vaccinated for hepatitis B. Furthermore, 87.2\% (395/453) of the participants had never been screened for hepatitis $\mathrm{B}$ or $\mathrm{C}$ before (Table 5).

\section{Discussion}

Hepatitis caused by hepatitis B and hepatitis C virus represents a widespread major health problem and it is very serious in the case of refugees that often live in circumstances that facilitate the spread of infectious diseases, such as HBV and HCV [5]. Globally, $45 \%$ of the population live in areas with high HBV prevalence, while another $40 \%$ live in regions with intermediate prevalence [27]. Although direct comparison is difficult because of limited published data in Africa, we have tried to compare our results with other high-risk groups and refugees found in other countries, but originated from Africa.

The prevalence of hepatitis B surface antigen ( $\mathrm{HBsAg}$ ) in the present study among refugees was $7.3 \%$, which was classified as an intermediate prevalence [28]. The probable reasons for this intermediate prevalence might be due to a lack of knowledge about the transmission and the prevention of ways of the infection, having multiple sexual partners, and a large number of study participants were not vaccinated from their origin of country. Another possible explanation could be due to the origin of the country, the majority of them were from South Sudan, which has a high prevalence of HBV infection, $23.8 \%$ [29]. In addition, sexual promiscuity and scarification have been identified as common risk factors for HBV infection [30].

The current finding was much lower than reports from South Sudan among high- risk groups, 11\% [18], and $26 \%$ [31]. Similarly, it was less than studies done in South Sudan, 12.3\% [32], and central Sudan, 17.5\% [33]. The variation could be due to differences in the study period, or sample size difference. Our result was congruent with a previous national pooled prevalence of $7.4 \%$, in Ethiopia [14], and among pregnant women in Sudan, $7.5 \%$ [34]. In contrast, it was higher than previous studies in Ethiopia conducted at different risk groups: $3.0 \%$, measured among women during delivery, $4.7 \%$ among blood donors, $6.0 \%$ among waste handlers, $4.2 \%$ in a military camp [35-38]. However, it was lower than studies done in

Table 5 Knowledge, Attitude and Practice assessment on HBV and HCV infection among study participants in Gambella, Ethiopia, $2018(n=453)$

\begin{tabular}{|c|c|c|}
\hline Knowledge assessment questions & Yes (\%) & No (\%) \\
\hline Have you ever heard about HBV and HCV infection? & $94(20.8)$ & $359(79.2)$ \\
\hline Is hepatitis transmitted through sex? & $61(13.5)$ & $392(86.5)$ \\
\hline Can you get hepatitis infection through body fluid contact? & $39(8.6)$ & $414(91.4)$ \\
\hline Do HBV and HCV cause liver cancer? & $50(11.0)$ & $403(89.0)$ \\
\hline Is there a vaccine for HBV? & $60(13.2)$ & $393(86.8)$ \\
\hline Is there effective treatment for HBV? & $127(28.0)$ & $326(72.0)$ \\
\hline Is there effective treatment for HCV? & $142(31.3)$ & $311(68.7)$ \\
\hline \multicolumn{3}{|l|}{ Attitude assessment questions } \\
\hline Do you perceive that HBV \& HCV can be transmitted through food? & $37(8.2)$ & $416(91.8)$ \\
\hline Do you think hepatitis infection is a curable disease? & $52(11.5)$ & $401(88.5)$ \\
\hline Do you think that hepatitis is a serious public health problem? & $110(24.3)$ & $343(75.7)$ \\
\hline Do you think that taking HBV vaccine is safe? & $123(27.2)$ & $330(72.8)$ \\
\hline \multicolumn{3}{|l|}{ Practice assessment questions } \\
\hline Have you received HBV vaccination? & $7(1.5)$ & $446(98.5)$ \\
\hline Have you ever been screened for HBV and HVC? & $58(12.8)$ & $395(87.2)$ \\
\hline Have you exchange of intravenous drug use? & $1(0.2)$ & $452(99.8)$ \\
\hline
\end{tabular}


Gondar among street dwellers, $10.9 \%$, among young males in all regions of Ethiopia, 10.8\% [39, 40], and South Sudan study among out patients in six clinics, $26.0 \%$ [30]. The above variations might be due to differences in study groups, level of exposure to the risks, test methodology, origin of country, and sample size.

The current study revealed a lower prevalence of hepatitis B than previous studies done in different African immigrants in the USA: Eritrean, 15.5\%, Sudanese, 9.1\% and Somalian, $8.3 \%$, whereas it was higher than Kenya, 5.9\%, Tanzania, 4.1\% Burundi, 3.1\% and Rwanda immigrants $3.0 \%$ [41]. Similarly, it was also lower than reports from immigrants in different parts of the world, such as from Bari-Italy, 8.3\% [42], from South-Europe, $11.9 \%$ [43], among Afghan refugees in Pakistan, 8.3\% [44], from India-Tibetan refugees, $8.9 \%$ [45]. This discrepancy might be related to the difference in test methods, larger sample sizes, study design and origin of the country. Our study showed higher prevalence of hepatitis B than previous studies among immigrants in different countries, UK, 5.0\% [9], India, 6.2\% [46], northern-Europe, $3.8 \%$ [47], and Kosovo, 2.9\% [48]. The reasons for these variations might be due to variation in geographical distribution as well as population differences in terms of lifestyle and good awareness about the transmission and prevention of the infection.

The worldwide prevalence of hepatitis $C$ is estimated to be $3.0 \%$ [3], with the highest prevalence $14.7 \%$ in Egypt [49]. According to the World health organization (WHO) classification, the prevalence of hepatitis $\mathrm{C}$ can be graded as high $(>3.5 \%)$, moderate (1.5-3.5\%), and low $(<1.5 \%)$ [50]. Based on the above evidence, the current study revealed an intermediate prevalence of anti-HCV, $2.0 \%$, which might be because of lack of knowledge about the transmission and prevention of HCV infection, lack of access to health care services, and the inability to obtain healthcare information from the media, or it could be due to the exposure of $\mathrm{HCV}$ in their country of origin.

This finding was congruent with an old study in Ethiopia among urban and rural populations, 2.0\% [51], however, it was relatively lower than previous studies from South Sudan, 3\% [30], and central Sudan, 2.2\% [52]. This study was higher than studies conducted in Ethiopia at different risk groups: among medical waste handlers $1.0 \%$ (16) among military personnel $0.2 \%$ (18) and $0.2 \%$ among blood donors [53]; in contrast, it was lower than among patients on antiretroviral treatment (ART), 4.3\% [54] and 5.8\% prevalence among blood donors [55]. These variations could be due to differences in the study group, test methodology, study setting, and sample size.

The prevalence of hepatitis $C$ in this study was lower than compared to refugees in different countries, such as
Italy, 4.5\% [42] and Greece, 2.3\% [5], whereas it was higher than previous studies from Malta, 0.6\% [46] and Germany, $1.9 \%$ [56]. The difference might be due to the difference in geographical location, origin of the refugees, and sample size.

There is no consensus on the role of gender as a risk factor for HBV and HCV infection [57]. The proportion of HBsAg positive rate was higher among male participants, 9.6\% (8/83) than female participants, 6.8\% (25/370). Similarly, anti-HCV positivity rate was higher among male participants, $4.8 \%(4 / 83)$ than female participants, $1.4 \%(5 /$ $370)$, however, the difference was not statistically significant $(P=0.083)$. This finding was comparable to a study conducted in Italy [42]. In contrast, a higher prevalence of HCV among females was reported in Yemen and Egypt $[58,59]$. However, further studies on sex-specific prevalence of HBV and HCV are needed.

During this study, the prevalence of anti-HCV showed a significant relationship with being between 18 and 29 $(P=0.003)$ and $30-41$ years old $(P=0.020)$, although the number of refugees positive for anti-HCV was quite limited, which limits the external validity of the $p$-value. This finding was consistent with studies conducted by Greenaway et al and $\mathrm{Lu}$ et al $[56,60]$. This significant relationship might be due to being between 18 and 29 years old, and 30-41 years old implies being an adult, often sexually active, more risk of HCV. Marital status, educational status, exchange of sharp materials with other persons, multiple sexual partners were not associated with either HBV or HCV infection [45]. Lack of significant association might be due to small sample size, and only 9 persons who were positive for $\mathrm{HCV}$, which means that the group of positivity is too small to find any significant and trustful relationship between sexual behavior, education and exchange of sharp materials, and the prevalence of HCV and HBV.

The current study assessed participant's knowledge, attitude, and practices about $\mathrm{HBV}$ and $\mathrm{HCV}$ infection. A huge lack of knowledge was observed among refugees about viral hepatitis, its mode of transmission, and the possibility of prevention by vaccination. This was consistent with a study by Alemairy et al in Sudan among barbers and women hairdressers, which reported below 50\% [61]. However, it was inconsistent with previous studies in Sudan among health care workers, which reported, 58.2\% had an average level of knowledge [62], and greater than $80 \%$ knew the transmission and the prevention mechanisms of HBV infection [63]. The variation might be due to educational level difference, the majority of our study participants were illiterate and elementary level, while in their studies the participants were health care workers, which have a relative advantage of health care services and information about HBV infection transmission and prevention ways. It was also incomparable to studies from 
Asian American immigrants and Chinese immigrants showed, 61 to $90 \%$ of participants knew that HBV and $\mathrm{HCV}$ infection can transmit through body fluid contact and unsafe sex, moreover the participants had information about $\mathrm{HBV}$ vaccination $[64,65]$.

With regard to refugees' attitudes, 8.2\% (37/453) have perceived that $\mathrm{HBV}$ and $\mathrm{HCV}$ infection can be transmitted by food. Similarly, studies conducted among Korean and Cambodian immigrants in the USA, revealed that food can be a source of hepatitis B transmission $[66,67]$. Almost seventy- 3 $\%$ (72.8\%) of the participants believed that a hepatitis B vaccine is not safe. In contrast, a study among Chinese immigrants in the USA have a positive attitude towards vaccination $[66,68]$.

In terms of refugees' practice, our result showed that there was a huge gap concerning screening and vaccination among the majority of the investigated refugees. Moreover, there was no routine or occasional vaccination of adults against HBV in the camp. This finding was incomparable to the previous study among immigrants in British stating that $71 \%$ screened for $\mathrm{HBsAg}$ and $44 \%$ received both testing and vaccination [69].

\section{Limitations of the study}

Financial reasons made it impossible to perform all diagnostic markers of hepatitis, which would have been helpful to differentiate chronic infection from acute infections and to determine viral load. In addition, small sample size in our study might limit the association of risk factors with $\mathrm{HBV}$ and $\mathrm{HCV}$, and the cross-sectional nature of this study makes it difficult to attribute causality to the observed associations. Furthermore, the representativeness of this finding is limited because our study conducted only in one refugee camp. Therefore, large scale longitudinal study design is needed for the future.

\section{Conclusion}

In general, the prevalence of hepatitis $B$ and $C$ viruses was intermediate among study participants at Pugnido-I Camp refugee in Gambella, Ethiopia. The prevalence of hepatitis $C$ virus was found to increase with age, but no other risk factors for either virus were identified as significant. Refugees' understanding of hepatitis B and C was limited. This indicates the need for screening policy to be implemented and integrated with other health services and awareness creation about the infection in all refugee camps of Gambella, Ethiopia.

\section{Supplementary information}

Supplementary information accompanies this paper at https://doi.org/10. 1186/s12889-020-08893-1.

Additional file 1: A questionnaire used for collect data on sociodemographic, risk factors, knowledge, attitude, and practice of refugees towards HBV and HCV infections.

\section{Abbreviations}

HBV: Hepatitis B virus; HCV: Hepatitis C virus; HBsAg: Hepatitis B surface antigen; WHO: World Health Organization; KAP: Knowledge, Attitude and Practice

\section{Acknowledgments}

We thank Addis Ababa University and Ethiopian Public Health Institute for supporting this study. We are also grateful to the Department of Medical Laboratory Sciences for giving us an ethical clearance for this study. We are thankful to Marrigje Jacoba Kreuger (MD) for her review of the manuscript. Our heartfelt gratitude goes to all study participants who gave us written consent to participate in this study.

\section{Authors' contributions}

AA participated in the conception of research idea, design of the study, data collection in the field and carried out the analysis; DA involved in study design, statistical analysis and drafted the manuscript. HM, BM and DK helped in the interpretation of the data, supervised the study and reviewed the manuscript. All authors read and approved the final manuscript.

\section{Funding}

No funding was obtained for this study.

\section{Availability of data and materials}

The datasets used and/or analyzed during the current study are available from the corresponding author on reasonable request.

Ethics approval and consent to participate

Ethical approval was obtained from Department of Medical Laboratory Sciences, College of Health Sciences, Addis Ababa University. In addition, written permission was obtained from the office of the Administration of Refugees and Returnees Affair and UNHCR, Ethiopia. Samples were collected after written consent was obtained from the participants and confidentiality of the test results was kept. Participants with positive tests for $\mathrm{HBsAg}$ and anti-HCV antibody were linked to the physician for further management.

\section{Consent for publication}

Not applicable.

\section{Competing interests}

The authors declare that they have no competing interests.

\section{Author details}

'Department of Medical Laboratory Sciences, Ethiopian Airport, Addis Ababa, Ethiopia. ${ }^{2}$ Department of Medical Laboratory Sciences, College of Health Sciences, Addis Ababa University, Addis Ababa, Ethiopia. ${ }^{3}$ Department of Medical Laboratory Sciences, College of Health Sciences, Assosa University, Assosa, Ethiopia.

Received: 15 January 2019 Accepted: 11 May 2020

Published online: 19 May 2020

\section{References}

1. Barnett ED. Infectious disease screening for refugees resettled in the United States. CID. 2004;39(6):833-41.

2. Mixson-Hayden T, Lee D, Ganova-Raeva L, Drobeniuc J, Stauffer WM, Teshale E, et al. Hepatitis B virus and hepatitis C virus infections in United States-bound refugees from Asia and Africa. Am J Trop Med Hyg. 2014;90(6):1014-20.

3. Sharma S, Carballo M, Feld JJ, Janssen HL. Immigration and viral hepatitis. J Hepatol. 2015;63(2):515-22.

4. Heidrich B, Cetindere A, Beyaz M, Stahmeyer JT, Basaran MM, Braynis B, et al High prevalence of hepatitis markers in immigrant populations: a prospective screening approach in a real-world setting. Eur J Gastrol Hepatol. 2014;26(10):1090-7.

5. Roussos A, Goritsas C, Pappas T, Spanaki M, Papadaki P, Ferti A. Prevalence of hepatitis B and C markers among refugees in Athens. World J Hepatol. 2003;9(5):993.

6. Schilling T, Rauscher S, Menzel C, Reichenauer S, Müller-Schilling M, Schmid S, et al. Migrants and refugees in Europe: challenges, experiences and contributions. Visc Med. 2017;33(4):295-300. 
7. Owiti JA, Greenhalgh T, Sweeney L, Foster GR, Bhui KS. Illness perceptions and explanatory models of viral hepatitis B \& C among immigrants and refugees: a narrative systematic review. BMC Public Health. 2015;15(1):151.

8. Hahné SJ, Veldhuijzen IK, Wiessing L, Lim T-A, Salminen M, van de Laar M. Infection with hepatitis $B$ and $C$ virus in Europe: a systematic review of prevalence and cost-effectiveness of screening. BMC Infect Dis. 2013;13(1):181.

9. Evlampidou I, Hickman M, Irish C, Young N, Oliver I, Gillett S, et al. Low hepatitis B testing among migrants: a cross-sectional study in a UK city. Br J Gen Pract. 2016;66(647):e382-e91.

10. Lazarus J. Global policy report on the prevention and control of viral hepatitis in WHO member states. Geneva: World Health Organization; 2014.

11. Allain J-P, Candotti D, Soldan K, Sarkodie F, Phelps B, Giachetti C, et al. The risk of hepatitis B virus infection by transfusion in Kumasi, Ghana. Blood. 2003;101(6):2419-25

12. Burnett R, Francois G, Kew M, Leroux-Roels G, Meheus A, Hoosen A, et al. Hepatitis B virus and human immunodeficiency virus co-infection in subSaharan Africa: a call for further investigation. Liver Int. 2005;25(2):201-13.

13. Madhava V, Burgess C, Drucker E. Epidemiology of chronic hepatitis $C$ virus infection in sub-Saharan Africa. Lancet Infect Dis. 2002;2(5):293-302.

14. Belyhun Y, Maier M, Mulu A, Diro E, Liebert UG. Hepatitis viruses in Ethiopia: a systematic review and meta-analysis. BMC Infect Dis. 2016:16(1):761.

15. UNHCR. Ethiopia refugee response plan; 2018. p. 1-68.

16. Howell J, Ladep NG, Lemoin M, Thursz MR, Taylor-Robinson SD. Hepatitis B in sub-saharan Africa. S Sudan Med J. 2014;7(3):59-61.

17. Badawi M, Atif M, Mustafa Y. Systematic review and meta-analysis of HIV, HBV and HCV infection prevalence in Sudan. Virol J. 2018;15(1):1-16.

18. Kirbak ALS. Sero-prevalence for hepatitis B virus among pregnant women attending antenatal clinic in juba teaching hospital, republic of South Sudan. Pan Afr Med. 2017;26:72.

19. Charan J, Biswas T. How to calculate sample size for different study designs in medical research? Indian J Psychol Med. 2013;35(2):121.

20. Kew MC. Hepatitis B virus/human immunodeficiency virus co-infection and its hepatocarcinogenic potential in Sub-Saharan Black Africans. Hepat Mon. 2012;12(10 HCC):e7876.

21. Shalaby S, Kabbash I, El Saleet G, Mansour N, Omar A, El Nawawy A. Hepatitis B and C viral infection: prevalence, knowledge, attitude and practice among barbers and clients in Gharbia governorate, Egypt. East Mediterr Health J. 2010;16:10-7.

22. Haqul N, Hassali MA, Shafie AA, Saleem F, Farooqui M, Aljadhey H. A cross sectional assessment of knowledge, attitude and practice towards Hepatitis B among healthy population of Quetta, Pakistan. BMC Public Health. 2012; 12(1):692.

23. Gebrecherkos T, Girmay G, Lemma M, Negash M. Knowledge, attitude, and practice towards Hepatitis B virus among pregnant women attending antenatal care at the University of Gondar comprehensive specialized hospital, Northwest Ethiopia. Int J Hepatol. 2020;2020:1-10.

24. Mohamed EA, Giama NH, Shaleh HM, Kerandi L, Oseini AM, Ahmed Mohammed $\mathrm{H}$, et al. Knowledge, attitudes, and behaviors of viral hepatitis among recent African immigrants in the United States: a community based participatory research qualitative study. Front Public Health. 2020;8:25.

25. Bendal R, Afifi A. Comparison of stopping rules in forward regression. J Am Stat Assoc. 1977;72(357):46-53.

26. Mickey RM, Greenland S. The impact of confounder selection criteria on effect estimation. Am J Epidemiol. 1989;129(1):125-37.

27. MacLachlan JH, Cowie BC. Hepatitis B virus epidemiology. Cold Spring Harb Perspect Med. 2015;5(5):a021410.

28. Ott J, Stevens G, Groeger J, Wiersma S. Global epidemiology of hepatitis B virus infection: new estimates of age-specific HBsAg seroprevalence and endemicity. Vaccine. 2012;30(12):2212-9.

29. Schweitzer A, Horn J, Mikolajczyk RT, Krause G, Ott JJ. Estimations of worldwide prevalence of chronic hepatitis $B$ virus infection: a systematic review of data published between 1965 and 2013. Lancet. 2015;386(10003):1546-55.

30. McCarthy MC, El-Tigani A, Khalid IO, Hyams KC. Hepatitis B and C in Juba, southern Sudan: results of a serosurvey. Trans R Soc Trop Med Hyg. 1994; 88(5):534-6

31. Elsheikh RM, Daak AA, Elsheikh MA, Karsany MS, Adam I. Hepatitis B virus and hepatitis C virus in pregnant Sudanese women. Virol J. 2007;4(1):104.

32. Ahmed S, Sanyal R, SCEDROU P, Ahmed M. Hepatitis B surface antigen in South Sudan. J Commun Disord. 1984;16(4):330-1.

33. Elshafie S. The prevalence of hepatitis B surface antigen in the Gezira (Sudan). Afr J Med Med Sci. 1992;21(1):61-3.
34. Abuelgasim MH, Baraka MBK. Prevalence of hepatitis B infection among pregnant women at Khartoum teaching hospital, Sudan. J US-China Med Sci. 2015;12(2):58-63.

35. Tegegne D, Desta K, Tegbaru B, Tilahun T. Seroprevalence and transmission of Hepatitis B virus among delivering women and their new born in selected health facilities, Addis Ababa, Ethiopia: a cross sectional study. BMC Res Notes. 2014;7(1):239.

36. Kabato A, Weldearegay G. Prevalence and associated risk factors of hepatitis $B$ and hepatitis $C$ virus among volunteer blood donors in Arba Minch blood Bank SNNPR, Ethiopia. J Med Lab Diagn. 2016;7:20-7.

37. Anagaw B, Shiferaw Y, Anagaw B, Belyhun Y, Erku W, Biadgelegn F, et al. Seroprevalence of hepatitis $B$ and $C$ viruses among medical waste handlers at Gondar town health institutions, Northwest Ethiopia. BMC Res Notes. 2012;5(1):55.

38. Birku T, Gelaw B, Moges F, Assefa A. Prevalence of hepatitis B and C viruses infection among military personnel at Bahir Dar armed forces general hospital, Ethiopia. BMC Res Notes. 2015;8(1):737.

39. Moges F, Kebede Y, Kassu A, Mulu A, Tirunch M, Degu G, et al. Seroprevalence of HIV, hepatitis B infections and syphilis among street dwellers in Gondar city, Northwest Ethiopia. Ethiop J Health Dev. 2006;20(3):1-6.

40. Kefene H, Rapicetta M, Rossi G, Bisanti L, Bekura D, Morace G, et al. Ethiopian national hepatitis B study. J Med Virol. 1988;24(1):75-84.

41. Rein DB, Lesesne SB, O'fallon A, Weinbaum CM. Prevalence of hepatitis B surface antigen among refugees entering the United States between 2006 and 2008. Hepatology. 2010;51(2):431-4

42. Tafuri S, Prato R, Martinelli D, Melpignano L, De Palma M, Quarto M, et al. Prevalence of Hepatitis B, C, HIV and syphilis markers among refugees in Bari, Italy. BMC Infect Dis. 2010;10(1):213.

43. Katsanos K, Resuli B, Tsianos E. Hepatitis B in Albanian refugees across Southeast Europe: from epidemiology to vaccination and prevention policy. Ann Gastroenterol. 2004;17:160-67.

44. Quddus A, Luby SP, Jamal Z, Jafar T. Prevalence of hepatitis B among afghan refugees living in Balochistan, Pakistan. Int J Infect Dis. 2006;10(3):242-7.

45. Stevens K, Palmo T, Wangchuk T, Solomon S, Dierberg K, Hoffmann CJ. Hepatitis B prevalence and treatment needs among Tibetan refugees residing in India. J Med Virol. 2016;88(8):1357-63.

46. Padovese V, Egidi A, Melillo TF, Farrugia B, Carabot P, Didero D, et al. Prevalence of latent tuberculosis, syphilis, hepatitis B and $C$ among asylum seekers in Malta. J Public Health. 2013;36(1):22-7.

47. Chu JJ, Wörmann T, Popp J, Pätzelt G, Akmatov MK, Krämer A, et al. Changing epidemiology of hepatitis $B$ and migration - a comparison of six Northern and North-Western European countries. Eur J Pub Health. 2012; 23(4):642-7.

48. Chironna M, Germinario C, Lopalco PL, Carrozzini F, Quarto M. Prevalence of hepatitis virus infections in Kosovar refugees. Int J Infect Dis. 2001;5(4):209-13.

49. Guerra J, Garenne M, Mohamed M, Fontanet A. HCV burden of infection in Egypt: results from a nationwide survey. J Viral Hepat. 2012;19(8):560-7.

50. Hanafiah KM, Groeger J, Flaxman AD, Wiersma ST. Global epidemiology of hepatitis $C$ virus infection: new estimates of age-specific antibody to HCV seroprevalence. Hepatology. 2013;57(4):1333-42.

51. Frommel D, Tekle-Haimanot R, Berhe N, Aussel L, Verdier M, Preux P-M, et al. A survey of antibodies to hepatitis C virus in Ethiopia. Am J Trop Med Hyg. 1993:49(4):435-9.

52. Mudawi HM, Smith HM, Rahoud SA, Fletcher IA, Babikir AM, Saeed OK, et al Epidemiology of HCV infection in Gezira state of Central Sudan. J Med Virol. 2007:79(4):383-5.

53. Yami A, Alemseged F, Hassen A. Hepatitis B and C viruses infections and their association with human immunodeficiency virus: a cross-sectional study among blood donors in Ethiopia. Ethiop J Health Sci. 2011;21(1):67-75.

54. Atsbaha AH, Dejen TA, Belodu R, Getachew K, Saravanan M, Wasihun AG. Seroprevalence and associated risk factors for hepatitis $C$ virus infection among voluntary counseling testing and anti retroviral treatment clinic attendants in Adwa hospital, northern Ethiopia. BMC Res Notes. 2016:9(1):121.

55. Diro E, Alemu S. Blood safety \& prevalence of transfussion transmissible viral infections among donors at the Red Cross Blood Bank in Gondar University Hospital. Ethiop Med J. 2008;46(1):7-13.

56. Greenaway C, Ma AT, Kloda LA, Klein M, Cnossen S, Schwarzer G, et al. Correction: the Seroprevalence of Hepatitis $C$ antibodies in immigrants and refugees from intermediate and high endemic countries: a systematic review and meta-analysis. PLoS One. 2015;10(12):e0144567.

57. Kamal SM. Acute hepatitis C: a systematic review. Am J Gastroenterol. 2008; 103(5):1283. 
58. Gacche RN, Al-Mohani SK. Seroprevalence and risk factors for hepatitis $C$ virus infection among general population in central region of Yemen. Hepat Res Treat. 2012;2012:689726.

59. Bakr I, Rekacewicz C, El Hosseiny M, Ismail S, El Daly M, El-Kafrawy S, et al. Higher clearance of hepatitis $C$ virus infection in females compared with males. Gut. 2006;55(8):1183-7.

60. Lu L, Nakano T, He Y, Fu Y, Hagedorn CH, Robertson BH. Hepatitis C virus genotype distribution in China: predominance of closely related subtype $1 \mathrm{~b}$ isolates and existence of new genotype 6 variants. J Med Virol. 2005;75(4):538-49.

61. Alemairy A. P082 HIV, HBV and HCV knowledge and practice among barbers and women hairdressers (coifeurs): a cross sectional study in khartoum state 2015. Am J Epidemiol Infect Dis. 2016;4:84-90.

62. Mursy SM-eM, Mohamed SOO. Knowledge, attitude, and practice towards Hepatitis B infection among nurses and midwives in two maternity hospitals in Khartoum, Sudan. BMC Public Health. 2019;19(1):1597.

63. Elsheikh T, Balla SA, Abdalla AA, Elgasim M, Swareldahab Z, Bashir AA. Knowledge, attitude and practice of heath care workers regarding transmission and prevention of Hepatitis B virus infection, White Nile State, Sudan, 2013. Am J Health Res. 2016:4(2):18-22.

64. Carabez RM, Swanner JA, Yoo GJ, Ho M. Knowledge and fears among Asian Americans chronically infected with hepatitis B. J Cancer Educ. 2014;29(3):522-8.

65. Cotler S, Cotler S, Xie H, Luc B, Layden T, Wong S. Characterizing hepatitis B stigma in Chinese immigrants. J Viral Hepat. 2012;19(2):147-52.

66. Choe JH, Chan N, Do HH, Woodall E, Lim E, Taylor VM. Hepatitis B and liver cancer beliefs among Korean immigrants in Western Washington: report of a qualitative study. Cancer. 2005:104(S12):2955-8.

67. Burke NJ, Do HH, Talbot J, Sos C, Svy D, Taylor VM. Chumnguh thleum: understanding liver illness and hepatitis B among Cambodian immigrants. J Community Health. 2011;36(1):27-34.

68. Chang ET, Nguyen BH, So S. Attitudes toward hepatitis B and liver cancer prevention among Chinese Americans in the San Francisco Bay Area, California. Asian Pac J Cancer Prev. 2008;9(4):605-13.

69. Hislop TG, Bajdik CD, Teh C, Lam W, Tu S-P, Yasui Y, et al. Hepatitis B testing and vaccination in immigrants attending English as a second language classes in British Columbia, Canada. Asian Pac J Cancer Prev. 2009;10(6):997.

\section{Publisher's Note}

Springer Nature remains neutral with regard to jurisdictional claims in published maps and institutional affiliations.

Ready to submit your research? Choose BMC and benefit from:

- fast, convenient online submission

- thorough peer review by experienced researchers in your field

- rapid publication on acceptance

- support for research data, including large and complex data types

- gold Open Access which fosters wider collaboration and increased citations

- maximum visibility for your research: over $100 \mathrm{M}$ website views per year

At BMC, research is always in progress.

Learn more biomedcentral.com/submissions 